Published in final edited form as:

Nutr Rev. 2007 August ; 65(8 Pt 2): S102-S104.

\title{
Vitamin D Receptor Gene (VDR) Associations with Cancer
}

\author{
Martha L. Slattery, PhD, MPH \\ Department of Epidemiology, University of Utah School of Medicine, Salt Lake City, Utah, USA.
}

In 1969 the nuclear vitamin D receptor (VDR) for $1 \alpha 25(\mathrm{OH})_{2} \mathrm{D}_{3}$ was discovered. ${ }^{1}$ Since then, the role of VDR in the endocrine system and its presence and function in over 30 tissues and organs has been examined. VDR has been shown to be involved in insulin-like growth factor (IGF) signaling, in inflammation and estrogen-related pathways, and in the activation and regulation of vitamin $\mathrm{D}$ and calcium. The involvement of VDR in multiple pathways and points of convergence within these pathways indicates the potential importance of VDR in the etiology of cancer. In 1997, Ingles et al. ${ }^{2}$ reported an association with variants of the VDR gene and prostate cancer, supporting the hypothesized importance of $V D R$ and the risk of developing cancer. Since the work of Ingles et al. ${ }^{2}$, the association of the $V D R$ gene with several cancers has been examined.

Most studies of VDR and cancer have focused on six polymorphisms: 1) the rs 10735810 or Fok1 polymorphism on exon 2, 2) rs1544410 or Bsm1 on intron 8, 3) rs731236 or Taq1 on exon 9,4 ) rs7975232 or Apa1 on intron 8, 5) rs757343 or Tru91 on intron 8, and 6) the poly (A) mononucleotide repeat at the 3'-UTR section of the gene. Different polymorphisms may have different functions depending on the location. ${ }^{3}$ The Fok1 polymorphism is near the $5^{\prime}$ UTR region of the gene within the DNA-binding domain. The other polymorphisms are close to the $3^{\prime}$-UTR region of the gene, the ligand-binding domain, and may have different functions than Fok1 based on their location. The polymorphisms examined near the $3^{\prime}$-UTR region of the gene appear to be in linkage disequilibrium, and the allele frequencies for these polymorphisms appear to vary by race. ${ }^{4}$ Most studies of $V D R$ and cancer have been conducted predominantly in non-Hispanic white populations. Studies have examined associations between $V D R$ polymorphisms and colorectal adenomas and cancer, prostate cancer, breast cancer, bladder cancer, and melanoma.

Studies of the association between VDR polymorphisms and colorectal adenomas have shown a $20 \%$ to $80 \%$ reduced risk of colorectal adenoma among people with the B Bsm1, f Fok1, and the u Tur91 alleles. 5,6 Not all studies have observed reduced risk with the Fok1 polymorphism. 5 Similar associations have been observed for colorectal cancer and the VDR gene as for adenomas. ${ }^{7-10}$ There are suggestions in the literature that polymorphisms at the $3^{\prime}$-UTR of the gene and those at the 5'-UTR region may be associated differently with colon and rectal cancer. As with the reported associations for colorectal adenomas and the Fok1 VDR polymorphisms, findings are not universal. Studies examining haplotypes and colorectal cancer have observed the BLF halotype to increase risk of colon but not rectal cancer. ${ }^{4}$

Associations between $V D R$ polymorphisms and prostate cancer are similar to those reported for colorectal cancer. Ingles et al. ${ }^{2}$ reported over a 4-fold increased risk of prostate cancer among men with more than 20 repeats of the poly(A) genotype; however, Andersson et al. ${ }^{11}$ reported over a 4-fold increased risk among those with short repeats. Cicek et al. ${ }^{12}$ observed that polymorphisms at both the 5'-UTR and 3'-UTR regions of the genes were associated with a $40 \%$ to $70 \%$ reduced risk of prostate cancer, and that the fbaT haplotype was associated with

Please address all correspondence to: Dr. Martha Slattery, Professor of Epidemiology, University of Utah School of Medicine, 30 North 1900 East, AC 230, Salt Lake City, UT 84117, USA; Phone: 801-585-6955; Fax: 801-581-3623; E-mail: marty.slattery @ hsc.utah.edu.. 
a $50 \%$ reduced risk of prostate cancer. Xu et al. ${ }^{13}$ showed that the ff genotype of FokI was associated with more aggressive prostate tumors. Some studies have not shown an association between the VDR polymorphisms and prostate cancer. ${ }^{14,15}$

McCullough et al. ${ }^{16}$ examined the VDR gene and breast cancer, observing a $20 \%$ reduced risk among women with a B allele of the Bsm1 polymorphism. Ingles et al. ${ }^{17}$ reported a significant increased risk of breast cancer among Latina women in a multi-ethnic cohort with the SS genotype relative to the LL poly(A) and an inverse association with the bb genotype of the Bsm1 polymorphism. Others have reported increased risk of breast cancer among Caucasians for the aa (vs. AA) and the TT (vs tt) genotypes. ${ }^{18,19}$

Mittal et al. ${ }^{20}$ observed a 2 -fold increased risk of bladder cancer among people carrying the FF genotype. Li et al. ${ }^{21}$ observed a significant decreased risk of melanoma among individuals with the $t$ allele of the TaqI polymorphism and an increased risk of melanoma among individuals carrying the $f$ allele of the FokI polymorphism.

Epidemiological studies reporting the association between $V D R$ polymorphisms and cancer have repeatedly noted that the underlying characteristics of the population modify the associations between $V D R$ and cancer. Significant dietary interactions between $V D R$ and cancer have been observed for calcium, vitamin D, total energy intake, and dietary fat. In a study by Slattery et al., ${ }^{9}$ in the presence of low calcium and low energy, the SS and BB genotypes reduced risk of rectal cancer, while the opposite association was observed for proximal colon tumors. Wong et al. ${ }^{8}$ observed a stronger association between the Fok1 polymorphism and colorectal cancer in the presence of low calcium and low fat intake. McCullough et al. ${ }^{16}$ reported that the association between the BsmI and TaqI VDR polymorphisms and breast cancer had the greatest reduced risk among individuals with low calcium intake; Ingles et al. ${ }^{5}$ and Kim et al. ${ }^{6}$ reported that associations between FokI and BsmI and colorectal adenomas were strongest among individuals with low dietary calcium and vitamin D intake.

Other factors, including aspirin/NSAID use, body mass index (BMI), and age have been shown to interact with $V D R$ to alter risk of colorectal cancer in the following manner: greater risk reduction of colorectal cancer associated with the SS and BB genotypes among those who do not use aspirin/NSAIDS, ${ }^{22}$ stronger associations for colon cancer with BMI for those with the SS or BB genotypes, ${ }^{23}$ and stronger associations for BsmI and poly(A) VDR polymorphisms among those who were older. ${ }^{9}$ Additionally, VDR has been shown to interact significantly with the androgen receptor gene 24 and the leptin gene (unpublished data) to alter the risks of colon and rectal cancer. Some of the inconsistencies in the reported associations between VDR polymorphisms and cancer could stem from underlying different characteristics of the populations being studied.

In summary, $V D R$ appears to be important for several cancers. It is important to note, however, that not all polymorphisms appear to have the same association with cancer, and the site of cancer may further dictate which polymorphisms might be the most important. Given these associations, it is important to examine the relationship between other polymorphisms in other areas of the $V D R$ gene and cancer. Because $V D R$ is potentially involved in many pathways, it is important to evaluate the associations between VDR and other diet, lifestyle, and environmental factors as they relate to cancer. A key element of future research is obtaining a better understanding of the functionality of the VDR gene.

\section{REFERENCES}

1. Norman AW. Minireview: vitamin D receptor: new assignments for an already busy receptor. Endocrinology 2006;147:5542-5548. [PubMed: 16946007] 
2. Ingles SA, Ross RK, Yu MC, et al. Association of prostate cancer risk with genetic polymorphisms in vitamin D receptor and androgen receptor. J Natl Cancer Inst 1997;89:166-170. [PubMed: 8998186]

3. Zmuda JM, Cauley JA, Ferrell RE. Molecular epidemiology of vitamin D receptor gene variants. Epidemiol Rev 2000;22:203-217. [PubMed: 11218372]

4. Sweeney C, Curtin K, Murtaugh MA, Caan BJ, Potter JD, Slattery ML. Haplotype analysis of common vitamin D receptor variants and colon and rectal cancers. Cancer Epidemiol Biomarkers Prev 2006;15:744-749. [PubMed: 16614118]

5. Ingles SA, Wang J, Coetzee GA, Lee ER, Frankl HD, Haile RW. Vitamin D receptor polymorphisms and risk of colorectal adenomas (United States). Cancer Causes Control 2001;12:607-614. [PubMed: 11552708]

6. Kim HS, Newcomb PA, Ulrich CM, et al. Vitamin D receptor polymorphism and the risk of colorectal adenomas: evidence of interaction with dietary vitamin D and calcium. Cancer Epidemiol Biomarkers Prev 2001;10:869-874. [PubMed: 11489753]

7. Slattery ML, Yakumo K, Hoffman M, Neuhausen S. Variants of the VDR gene and risk of colon cancer (United States). Cancer Causes Control 2001;12:359-364. [PubMed: 11456232]

8. Wong HL, Seow A, Arakawa K, Lee HP, Yu MC, Ingles SA. Vitamin D receptor start codon polymorphism and colorectal cancer risk: effect modification by dietary calcium and fat in Singapore Chinese. Carcinogenesis 2003;24:1091-1095. [PubMed: 12807755]

9. Slattery ML, Neuhausen SL, Hoffman M, et al. Dietary calcium, vitamin D, VDR genotypes and colorectal cancer. Int J Cancer 2004;111:750-756. [PubMed: 15252846]

10. Slattery M, Murtaugh M, Caan B, Wolff R, Ma KNI, Samowitz W. Association between dietary fats and VDR genotypes and colon and rectal cancer. Int J Cancer Prev 2004;1:193-206.

11. Andersson P, Varenhorst E, Soderkvist P. Androgen receptor and vitamin D receptor gene polymorphisms and prostate cancer risk. Eur J Cancer 2006;42:2833-2837. [PubMed: 17010601]

12. Cicek MS, Liu X, Schumacher FR, Casey G, Witte JS. Vitamin D receptor genotypes/haplotypes and prostate cancer risk. Cancer Epidemiol Biomarkers Prev 2006;15:2549-2552. [PubMed: 17164384]

13. Xu Y, Shibata A, McNeal JE, Stamey TA, Feldman D, Peehl DM. Vitamin D receptor start codon polymorphism (Fokl) and prostate cancer progression. Cancer Epidemiol Biomarkers Prev 2003;12:23-27. [PubMed: 12540499]

14. Chokkalingam AP, McGlynn KA, Gao Y-T, et al. Vitamin D receptor gene polymorphisms, insulinlike growth factors, and prostate cancer risk: a population-based case-control study in China. Cancer Res 2001;61:4333-4336. [PubMed: 11389055]

15. Li H, Stampfer MJ, Hollis JB, et al. A prospective study of plasma vitamin D metabolites, vitamin D receptor polymorphisms, and prostate cancer. PLoS Med 2007;4:562-571.

16. McCullough ML, Stevens VL, Diver WR, et al. Vitamin D pathway gene polymorphisms, diet, and risk of postmenopausal breast cancer: a nested case-control study. Breast Cancer Res 2007;9:R9. [PubMed: 17244366]

17. Ingles SA, Garcia DG, Wang W, et al. Vitamin D receptor genotype and breast cancer in Latinas (United States). Cancer Causes Control 2000;11:25-30. [PubMed: 10680726]

18. Curran JE, Vaughan T, Lea RA, Weinstein SR, Morrison NA, Griffiths LR. Association of a vitamin D receptor polymorphism with sporadic breast cancer development. Int J Cancer 1999;83:723-726. [PubMed: 10597185]

19. Dunning AM, McBride S, Gregory J, et al. No association between androgen or vitamin D receptor gene polymorphisms and risk of breast cancer. Carcinogenesis 1999;20:2131-2135. [PubMed: 10545416]

20. Mittal RD, Manchanda PK, Bhat S, Bid HK. Association of vitamin-D receptor (Fok-1) gene polymorphism with bladder cancer in an Indian population. BJU Int 2007;99:933-937. [PubMed: 17378851]

21. Li C, Liu Z, Zhang Z, et al. Genetic variants of the vitamin D receptor gene alter risk of cutaneous melanoma. J Invest Dermatol 2007;127:276-280. [PubMed: 16990805]

22. Slattery ML, Samowitz W, Hoffman M, Ma KN, Levin TR, Neuhausen S. Aspirin, NSAIDs, and colorectal cancer: possible involvement in an insulin-related pathway. Cancer Epidemiol Biomarkers Prev 2004;13:538-545. [PubMed: 15066917] 
23. Slattery ML, Murtaugh M, Caan B, Ma KN, Wolff R, Samowitz W. Associations between BMI, energy intake, energy expenditure, VDR genotype and colon and rectal cancers (United States). Cancer Causes Control 2004;15:863-872. [PubMed: 15577288]

24. Slattery ML, Sweeney C, Murtaugh M, Ma KN, Caan BJ, Potter JD, Wolff R. Associations between vitamin $\mathrm{D}$, vitamin $\mathrm{D}$ receptor gene and the androgen receptor gene with colon and rectal cancer. Int J Cancer 2006;118:3140-3146. [PubMed: 16425262] 